\title{
PERANCANGAN ANIMASI 2D "ASAL USUL REOG PONOROGO" ADAPTASI CERITA RAKYAT SEBAGAI UPAYA PELESTARIAN BUDAYA INDONESIA
}

\author{
Patricia Abigail Wijaya ${ }^{1}$ Sultan Arif Rahmadianto ${ }^{2}$, Didit Prasetyo Nugroho $^{3}$ \\ Program Studi Desain Komunikasi Visual, Universitas Ma Chung \\ Email : 331710019@student.machung.ac.id, sultan.arif@machung.ac.id, \\ didit.nugroho@machung.ac.id
}

\begin{abstract}
Abstrak
Perkembangan teknologi telah membawa perubahan dalam berbagai aspek, salah satunya media pembelajaran dan hiburan. Cerita rakyat yang merupakan salah satu budaya literatur Indonesia, mulai kurang diminati dengan adanya bermacam budaya lain yang masuk ke Indonesia. Upaya pelestarian perlu dilakukan karena cerita rakyat mengandung nilai-nilai moral dan budaya yang baik, khususnya bagi anak-anak. Perancangan ini mengadaptasi cerita rakyat "Asal Usul Reog Ponorogo" dalam bentuk animasi 2D, sebagai video edukatif yang menghibur mengenai salah satu cerita rakyat kurang diketahui oleh anakanak. Metode penelitian dilakukan secara kualitatif dengan pengumpulan data yang berupa studi pustaka terhadap kesenian reog ponorogo, dan observasi serta wawancara terhadap anakanak sekolah dasar. Observasi dan wawancara dilakukan untuk memperoleh data ketertarikan anak terhadap cerita rakyat dan animasi. Analisis data dilakukan dengan metode $5 \mathrm{~W}+1 \mathrm{H}$ untuk memperoleh suatu sintesis dan konsep yang mendasari perancangan. Produksi perancangan animasi dimulai dari pembuatan alur, naskah, desain karakter dan background, storyboard, animatic, animation, coloring, dan kemudian postproduction. Animasi 2D yang dihasilkan berdurasi 4 menit dan detik dengan audio berupa musik, sound effects, dan voice over. Perancangan ini didukung dengan beberapa media yaitu, video teaser, poster, serta merchandise yang berupa gantungan kunci.
\end{abstract}

Kata kunci: budaya, animasi, cerita rakyat, Asal Usul Reog Ponorogo

\section{Abstract}

Technology developments have brought changes in a lot of aspects, one of them being education and entertainment medias. Folktale is one of Indonesian literature cultures that people have becoming less interested in as foreign cultures keep coming in Indonesia. A preservation attempt has to be made because folktale instills good morals and cultures values, especially to children. This design adapts the "Asal Usul Reog Ponorogo" folktale to a $2 D$ animation, as an educative and entertaining video about the folktale that is not much known to children.

The research is done qualitatively with literature study, observation, and interview as the data collecting methods. Observation and interview is done to obtain datas pertaining to children's interest in folktale and animation. Data analisys is done through the $5 \mathrm{~W}+1 \mathrm{H}$ method to acquire a synthesis and form a concept that found the design.

The animation production is done through the processes of writing plot, script, designing characters and backgrounds, storyboarding, making animatics, animating, coloring, and post-production editing. The $2 D$ animation that is produced is 4 minutes and 3 seconds long with audios such as musics, sound effects, and voice over. The design has some forms of supporting medias, such as a teaser video, a poster, and keychains as merchandise.

Keywords: culture, animation, folktale, Asal Usul Reog Ponorogo

\section{PENDAHULUAN}

Cerita rakyat merupakan tradisi lisan yang diwariskan dalam kehidupan masyarakat secara turun temurun. Pada masa lampau, cerita rakyat menjadi salah satu media pembelajaran untuk menanamkan nilai-nilai moral dan etika. Media pembelajaran adalah segala sesuatu yang digunakan untuk menyampaikan pesan agar dapat merangsang perhatian, minat, pikiran, dan perasaan pelajar dalam proses pembelajaran agar mencapai tujuan belajar (Santyasa, 2007).

Cerita rakyat disampaikan secara lisan karena pada zaman dahulu tulisan belum diciptakan. Pewarisan cerita rakyat dilakukan sebagai tradisi yang dilakukan dari generasi ke generasi (Kristanto, 2014). Budiman (1999, p.13) menyatakan bahwa jika setidaknya ada 2 generasi yang memahami suatu cerita rakyat, maka cerita tersebut pasti ada di dalam suatu generasi. Tradisi tersebut biasanya diwariskan ke generasi selanjutnya di dalam suatu kelompok. Masyarakat pada masa lampau menggunakan cerita rakyat untuk menanamkan nilai-nilai luhur kepada generasi selanjutnya. Nilai-nilai luhur yang terdapat pada cerita rakyat umumnya adalah tanggung jawab, kejujuran, disiplin, gotong-royong, dan lainnya.

Indonesia adalah negara yang kaya akan budaya. Budaya dan tradisi dalam masyarakat umumnya berupa upacara, kesenian, dan sastra (Kristanto, 2014). Seiring dengan berkembangnya jaman, asimilasi budaya tidak bisa dihindari sehingga pergeseran budaya pun terus berlangsung. Sebagai dampaknya, budaya otentik Indonesia semakin pudar dan kurang diminati. Masyarakat tidak memiliki banyak pengetahuan mengenai sastra Indonesia dan justru lebih berwawasan mengenai sastra luar negeri. Masalah ini juga terjadi di dunia perfilman. Film-film asing yang mengandung nilai-nilai luar jauh lebih digemari dibandingkan dengan film 
Indonesia dengan cerita dan budaya lokal. Pengaruh nilainilai tersebut mulai menggeser nilai-nilai budaya yang telah ada. Tentunya, menikmati budaya luar bukanlah hal yang buruk, tetapi minimnya representasi budaya sendiri dibanding budaya luar dalam berbagai media merupakan hal yang cukup memprihatinkan. Di tengah cepatnya peleburan budaya dan semakin terhubungnya dunia, bangsa Indonesia seharusnya bisa tetap mempertahankan nilai-nilai yang selama ini dipegang teguh.

Pendidikan karakter sebaiknya dilakukan sejak dini. Penanaman nilai-nilai yang baik pada anak-anak akan membangun karakter generasi muda yang sesuai dengan budaya Indonesia. Cerita rakyat merupakan media yang baik untuk pendidikan karakter karena selain mengandung pesan moral, juga mengajarkan mengenai budaya dan sejarah Indonesia (Kristanto, 2014). Penyampaian cerita rakyat sebaiknya dilakukan dengan efektif agar bisa diterima dan dimengerti oleh anak-anak, tetapi juga menarik bagi orang dewasa.

Cerita rakyat awalnya hanya disampaikan secara lisan, tetapi seiring dengan berkembangnya jaman sekarang sudah banyak cara dalam menyampaikannya. Anak-anak cenderung memiliki rentang perhatian yang pendek dan mudah bosan, khususnya sekarang di mana entertainment digital yang secara dominan berupa visual dan audio sangat mudah diakses dan digemari oleh anak-anak. Cara konvensional dalam bercerita seperti lisan dan tulisan sudah mulai sulit untuk menumbuhkan minat anak-anak. Animasi merupakan media yang efektif dalam mengadaptasi cerita rakyat karena memberikan informasi dengan cara yang menarik. Penelitian yang dilakukan oleh Handayani, Yetri, \& Putra (2018) menyatakan bahwa pembelajaran yang hanya mengandalkan buku teks sebagai sumber materi dan yang tampilannya tidak menarik akan membuat peserta didik bosan untuk belajar. Animasi yang menarik secara visual, alur cerita, dan dengan audio sebagai pendukung akan lebih mudah untuk diterima anak-anak. Informasi yang ingin disampaikan juga akan lebih mudah diresapi dan diingat karena berupa visual.

Rancangan animasi yang akan dikerjakan ini mengambil tema cerita rakyat Asal Usul Reog Ponorogo. Bidang yang diambil adalah animasi karena dunia animasi di Indonesia memiliki perkembangan dan potensi yang cukup besar sehingga merupakan media yang cukup efektif untuk menyampaikan cerita. Contohnya adalah hasil penelitian Putra (2013, p.24) yang menyatakan bahwa penggunaan media animasi dalam pembelajaran sejarah, meningkatkan minat para siswa terhadap pelajaran tersebut dan diharapkan dapat meningkatkan prestasi mereka dalam belajar, dan hasil penelitian N. Imamah (2012, p.36) yang menyatakan bahwa video animasi merupakan suatu media alternatif yang dapat digunakan sebagai guru dalam pembelajaran dan meningkatkan pemaham siswa tentang sistem kehidupan tumbuhan di dalam kehidupan sehari-hari.

\section{Tinjauan Pustaka dan Landasan Teori}

\section{Jurnal Ilmiah}

a. Berdasarkan jurnal yang berjudul "Adaptasi Cerita Rakyat Jayaprana dan Layonsari dalam Bentuk Animasi 2D" oleh Lestari dan Setiawan (2019), animasi merupakan seni modern yang penting digunakan untuk berbagai kepentingan, salah satunya adalah adaptasi cerita rakyat. Jurnal tersebut dapat digunakan sebagai referensi bagi perancangan ini dari segi pengumpulan dan analisis data serta menggunakan visual dan audio untuk merekonstruksi cerita rakyat yang akan ditampilkan.

b. Jurnal "Pembelajaran Sastra di Sekolah Dasar Berbasis Kearifan Lokal (Cerita Rakyat)" oleh Sumayana (2017) membahas mengenai kegunaan cerita rakyat sebagai materi pembelajaran sastra. Pembelajaran sastra di sekolah maupun di masyarakat semakin hilang. Artikel tersebut dapat digunakan sebagai referensi bagi perancangan ini dari segi penggunaan cerita rakyat sebagai pembelajaran dalam mengapresiasi sastra dan juga menanamkan nilai-nilai moral dan luhur.

c. Jurnal ilmiah "Pengembangan Media Pembelajaran Animasi Powtoon pada Mata Pelajaran Matematika di Kelas IV SD" oleh Awalia, Pamungkas dan Alamsyah (2019) membahas tentang permasalahan siswa kelas IV

SDN Karangtumaritis dalam belajar matematika. Faktor penyebab rendahnya pemahamam siswa akan matematika adalah kurangnya penggunaan media dalam pembelajaran dan kurangnya rasa antusias untuk belajar dari para siswa. Jurnal tersebut dapat digunakan sebagai referensi bagi perancangan ini dari segi penggunaan animasi yang menarik efektif dalam menyampaikan informasi kepada siswa SD.

d. Artikel ilmiah "Pengaruh Media Pembelajaran Digital Animasi dan Kepercayaan Diri terhadap Hasil Belajar Pendidikan Agama Islam Anak" oleh Panjaitan, Yetti, dan Nurani (2020) membahas tentang pengaruh penggunaan animasi dan kepercayaan diri dalam bidang Pendidikan Agama Islam dibandingkan dengan penggunaan digital storytelling. Jurnal tersebut dapat digunakan sebagai referensi bagi perancangan ini dari segi penggunaan animasi untuk memberi ilmu di bidang mata pelajaran sekolah dan juga menanamkan nilai-nilai moral kepada siswa SD.

e. Artikel "Pengembangan Media Video Animasi Untuk Meningkatkan Motivasi Belajar dan Karakter Kerja Keras Siswa Sekolah Dasar" oleh Wuryanti dan Kartowagiran (2016) membahas tentang efektifitas media video animasi untuk meningkatkan motivasi belajar dan karakter kerja keras siswa kelas V SD Gugus Sodo Kecamatan Paliyan. Artikel tersebut dapat digunakan sebagai referensi bagi perancangan ini dari segi penggunaan animasi sebagai media yang efektif dalam meningkatkan motivasi belajar dan penumbuhan karakter siswa.

2. Landasan Teori

a. Jenis-Jenis Animasi 
Menurut Soenyoto (2017) animasi dibagi menjadi beberapa jenis, yaitu cel shaded animation, puppet animation, object animation, clay animation, animasi 3D, dan animasi kartun 2D. 1) Cel Shaded Animation Cel Shaded Animation atau toonshading dibuat dengan cara membuat objek 3D terlebih dahulu dan kemudian di render agar terlihat seperti kartun 2D. 2) Puppet Animation

Animasi ini dibuat dengan menggunakan boneka yang memiliki ruas untuk digerakkan sehingga bisa berjalan, menengok dan melakukan gerakangerakan lainnya.

3) Object Animation

Animasi ini bisa dibuat dengan menggunakan berbagai macam objek seperti, pensil, mainan, bunga yang sedang mekar, manusia, dan sebagainya. Cara pembuatannya adalah dengan memotret pergerakan objek yang digunakan, lalu dijadikan sequence, yaitu runtutan gambar. 4) Clay Animation

Animasi ini dibuat dengan menggunakan palsticin yang bersifat lentur. Karakter dan benda pada animasi clay bisa diubah-ubah dan kemudian di foto setiap perubahannya untuk membuat rangkaian gambar (disebut juga animasi stop motion).

5) Animasi 3D

Animasi 3D merupakan sub bidang grafik komputer yang memanfaatkan kemajuan teknologi yang tinggi. Proses pembuatan animasi 3D memiliki beberapa tahap, yaitu modelling, shading/lighting, tekstur, surface, animasi, dan berakhir pada tahap rendering.

6) Animasi Kartun 2D

Dahulu, animasi 2D dibuat dengan menggunakan rangkaian gambar yang dibuat pada lembaran cel, tetapi kebanyakan animasi 2D sekarang sudah dibuat secara digital.

b. 12 Prinsip Animasi

Menurut Johnston dan Thomas dalam buku Illusion of Life (1981) terdapat 12 prinsip animasi yang menjadi dasar pembuatan animasi, yaitu:

1) Squash \& Stretch

Prinsip ini berdasar kepada sifat objek kaku yang tidak berubah bentuk ketika bergerak, sedangkan objek yang tidak kaku, akan berubah bentuk tergantung dari momentum dan keelastisan dari objek tersebut dan tetap memiliki volume yang sama.

\section{2) Anticipation}

Suatu pergerakan tidak dilakukan secara langsung. Pergerakan dalam animasi memiliki 3 urutan:

a. Bersiap untuk melakukan pergerakan

b. Pergerakan

c. Kelanjutan dari pergerakan Anticipation biasanya berlawanan arah dengan pergerakannya.

\section{3) Staging}

Staging adalah tampilan dari suatu aksi, sifat, ekspresi, atau perasaan yang disusun agar terlihat jelas dan mudah diterima oleh penonton. Tujuan dari staging adalah mengarahkan mata penonton ke mana sebuah aksi akan berlangsung sehingga aksi tersebut terlihat jelas.

4) Straight Ahead Action and Pose to Pose Ada 2 cara berbeda untuk membuat animasi suatu aksi. Teknik straight-ahead berarti menganimasikan aksi dari gambar pertama sampai akhir secara beurutan. Teknik pose-to-pose sedikit lebih rumit karena menggambar pose inti dari suatu aksi terlebih dahulu baru kemudian, menggambar inbetween untuk mengisi pergerakan animasi.

5) Follow Through and Overlapping Action Follow through adalah penyelesaian dari sebuah aksi. Umumnya, suatu aksi tidak langsung berhenti setelah terlaksana tetapi melebihi dari pergerakan aksi tersebut. Overlapping Action adalah sedikit perbedaan timing objek-objek pada suatu karakter agar terlihat lebih natural. Overlapping action membuat objek dan pergerakannya lebih menarik. 6) Slow In and Slow Out Pergerakan tubuh manusia, dan kebanyakan objek lainnya, butuh waktu untuk mempercepat gerak dan memperlambat gerak. Maka, animasi akan terlihat lebih realisits jika dibagian awal aksi dan akhir aksi lebih lambat dan memberi emphasis pada pose yang ekstrim.

7) Arcs

Kebanyakan aksi natural cenderung bergerak mengikuti lengkungan. Hal ini diaplikasikan dalam animasi agar terlihat lebih realistis.

8) Secondary Action

Menambahkan secondary action membuat aksi utama dan adegan lebih hidup, dan membantu aksi utama. Tujuan dari secondary action adalah memberi emphasis pada aksi utama dan tidak mengambil perhatian penonton dari aksi utama.

9) Timing

Timing adalah jumlah gambar atau frame pada sebuah aksi, yang merupakan cepat lambatnya suatu aksi. Sedikit gambar berarti lebih cepat sedangkan banyak gambar berarti lebih lambat.

10) Exaggeration

Exaggeration adalah sebuah efek yang berguna untuk animasi, karena animasi yang terlalu mengikuti kehidupan nyata terlihat statis dan kurang menarik. 
Tingkat exaggeration yang digunakan bergantung dari gaya animasi tersebut.

11) Solid Drawing

Dalam pembuatan animasi diperlukan adanya pemahaman yang cukup akan menggambar dalam ruang 3 dimensi dan memberi volume dan berat pada objek.

12) Appeal

Appeal adalah desain dari objek atau karakter yang menarik, memiliki penggambaran yang kuat, dan memiliki kepribadian.

c. Proses Penulisan dan Pembuatan Animasi

Christy Marx pada bukunya yang berjudul Writing for Animation, Comics, and Games (2012) mengatakan bahwa proses animasi (khususnya bagi animasi berseri di televisi) dibagi menjadi beberapa tahap sebagai berikut:

1) Pengembangan

2) Naskah

3) Perekaman Suara

4) Storyboard

5) Latar dan Desain Karakter

6) Animatic

7) Produksi Animasi

8) Post Production

d. Proses Kreatif Ilustrasi

Menurut Indiria Maharsi dalam bukunya yang berjudul Ilustrasi (2018), terdapat beberapa tahapan dalam proses pengerjaan ilustrasi yang dapat bermanfaat bagi perancangan ini dari segi pembuatan ilustrasi background dan desain karakter. Adapun prosesnya sebagai berikut:
1) Brief
2) Materi Subjek (Subject Matter)
3) Riset
4) Brainstorming
5) Medium
6) Bentuk (Form)
7) Visualisasi

\section{Metode}

Metode perancangan yang akan digunakan pada "Perancangan Animasi 2D "Asal Usul Reog Ponorogo" Adaptasi Cerita Rakyat Sebagai Upaya Pelestarian Budaya Indonesia" adalah metode kualitatif. Penelitian kualitatif adalah metodologi yang menyediakan alat-alat untuk memahami makna lebih dalam mengenai fenomena kompleks dan proses dalam praktik kegiatan atau kehidupan sosial (Denzin \& Lincoln, 2005). Strategi pendekatan yang akan digunakan dalam perancangan ini adalah pendekatan historis dan studi kasus.
Menurut Gall \& Borg (2003), penelitian sejarah adalah proses pencarian data yang sistematis untuk menjawab pertanyaan mengenai fenomena masa lampau dengan tujuan untuk memperoleh pemahaman lebih mengenai institusi masa kini, adat, tren, dan isu-isu dalam pendidikan. Penelitian ini dilakukan untuk merekonstruksi fakta masa lalu mengenai apa, siapa, kapan, di mana, dan bagaimana secara objektif, sistematis dan akurat yang dilakukan pada masa sekarang (Hernando, 2018). Data-data diperoleh dari pencarian pada sumber-sumber historis seperti catatan, dokumen resmi, dan barang peninggalan. Penelitian historis bermanfaat bagi perancangan ini dalam hal pengetahuan mengenai fakta sejarah, fenomena, dan budaya yang berkaitan dengan cerita rakyat Asal Usul Reog Ponorogo.

Menurut Creswell (2007), studi kasus adalah penilitian mengenai suatu aktivitas, fenomena, atau isu melalui satu atau banyak kasus dalam suatu sistem yang terbatas. Pada pendekatan studi kasus, peneliti mengeksplor suatu sistem tertutup (kasus) melalui pengumpulan data mendalam yang dilakukan dengan berbagai cara (seperti observasi, wawancara, materi audiovisual, dokumen, dan laporan). Studi kasus bermanfaat bagi perancangan ini dalam hal untuk mengetahui minat target audiens perancangan terhadap animasi dan cerita rakyat, serta mengetahui perilaku konsumsi media target audiens.

Data observasi diperoleh dari observasi partisipan, di mana peneliti mengamati gejala dan proses dalam kehidupan sehari-hari sekelompok partisipan. Observasi yang akan dilakukan oleh peneliti adalah observasi terus terang atau tersamar. Observasi ini dilakukan dengan menyatakan dengan jelas bahwa peneliti sedang melakukan penelitian, tetapi dalam suatu saat peneliti tidak terus terang dalam penelitian untuk mendapat data yang dirahasiakan (Sugiyono, 2015, p.312). Dalam rancangan ini, peneliti akan mengamati preferensi aktivitas, media, dan konten dari partisipan.

1. Observasi

Data observasi diperoleh dari observasi partisipan, di mana peneliti mengamati gejala dan proses dalam kehidupan sehari-hari sekelompok partisipan. Observasi yang akan dilakukan oleh peneliti adalah observasi terus terang atau tersamar. Observasi ini dilakukan dengan menyatakan dengan jelas bahwa peneliti sedang melakukan penelitian, tetapi dalam suatu saat peneliti tidak terus terang dalam penelitian untuk mendapat data yang dirahasiakan (Sugiyono, 2015, p.312). Dalam rancangan ini, peneliti akan mengamati preferensi aktivitas, media, dan konten dari partisipan.

2. Wawancara

Data wawancara diperoleh dari pertanyaan-pertanyaan pewawancara dan jawaban narasumber yang dijadikan hipotesis. Wawancara yang akan dilakukan peneliti adalah wawancara terstruktur, di mana peneliti menyiapkan instrumen penelitian berupa 
pertanyaanpertanyaan tertulis. Setiap responden akan diberi pertanyaan-pertanyaan yang sama, dan peneliti mencatat datanya (Sugiyono, 2015, p.320). Dalam rancangan ini, peneliti akan mewawancarai para narasumber secara langsung dan tidak langsung. Wawancara tidak langsung dilakukan dengan angket daring google forms. Wawancara ini berupaya untuk mengetahui pengetahuan dan ketertarikan narasumber terhadap cerita rakyat secara general dan cerita rakyat Asal Usul Reog Ponorogo, serta untuk mengetahui pendapat narasumber mengenai media animasi.

3. Studi Pustaka

Data studi pustaka diperoleh dari sumber-sumber ilmiah mengenai kesenian Reog Ponorogo. Hal ini meliputi sejarah Reog Ponorogo, versi-versi cerita, serta kesenian Reog Ponorogo pada masa modern. Berdasarkan metode pengumpulan data dalam perancangan ini, metode analisis yang sesuai adalah $5 \mathrm{~W}+1 \mathrm{H}$. Metode ini bertujuan untuk menjawab pertanyaanpertanyaan mengenai permasalahan kurangnya pengetahuan dan minat siswa sekolah dasar mengenai budaya literatur dan sejarah Indonesia. Hasil analisis dan sintesis konsep ini juga bermanfaat sebagai panduan dalam merancang penyajian cerita rakyat dengan media alternatif yang lebih digemari pada masa kini, salah satunya yaitu animasi. Analisis pertanyaan what (apa), membahas mengenai apa yang diketahui oleh siswa sekolah dasar mengenai cerita rakyat, khususnya cerita Asal Usul Reog Ponorogo. Analisis pertanyaan who (siapa), membahas mengenai target demografis yang efektif dalam perancangan ini sebagai upaya dalam melestarikan literatur cerita rakyat. Analisis pertanyaan why (mengapa), membahas mengenai alasan mengapa cerita rakyat merupakan budaya literatur yang perlu dilestarikan. Analisis pertanyaan when (kapan), membahas mengenai waktu yang efektif dalam dalam memberikan pembelajaran mengenai cerita rakyat kepada siswa sekolah dasar. Analisis pertanyaan where (di mana), membahas mengenai di mana peletakan video animasi yang tepat agar bisa menjangkau target audiens. Analisis pertanyaan how (bagaimana), membahas mengenai bagaimana merancang video animasi 2D yang mampu untuk mencapai tujuan perancangan. Dari uraian analisis tersebut diperoleh sintesis konsep sebagai panduan dalam "Perancangan Animasi 2D "Asal Usul Reog Ponorogo" Adaptasi Cerita Rakyat Sebagai

Upaya Pelestarian Budaya Indonesia" dengan data-data pendukung yang akan diuraikan lebih lanjut melalui bagan alir perancangan.

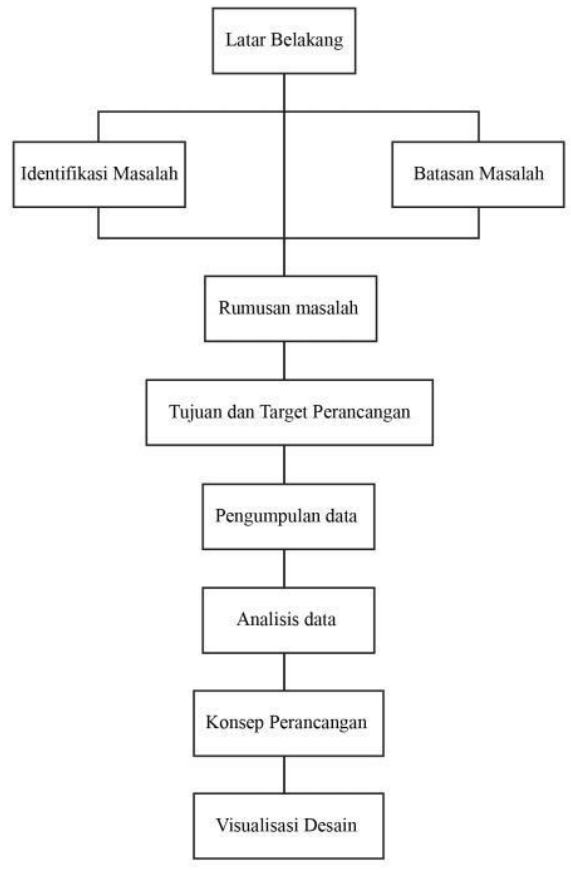

Gambar 1. Bagan Alur Perancangan

Berikut merupakan segmentasi target audiens pada "Perancangan Animasi 2D "Asal Usul Reog Ponorogo" Adaptasi Cerita Rakyat Sebagai Upaya Pelestarian Budaya Indonesia" yang diklasifikasikan berdasarkan aspek demografis dan geografis:

1. Segmentasi Demografis

a. Jenis kelamin: laki-laki dan perempuan

b. Usia: 6-12 tahun (anak-anak)

c. Pendidikan: Sekolah Dasar (SD)

2. Segmentasi Geografis

a. Segmentasi primer: masyarakat Kota Malang

b. Segmentasi sekunder: masyarakat luar Kota Malang di wilayah Indonesia yang memiliki akses internet dan fasih berbahasa Indonesia

\section{Analisis dan Pembahasan}

1. Studi Pustaka

Reog Ponorogo merupakan kesenian budaya yang berasal dari Jawa Timur. Seni Reog masih kental dengan hal-hal mistik dan kebatinan dan diyakini berasal dari Ponorogo. Menurut Departemen Pendidikan dan Kebudayaan (1978-1979), terdapat lima versi cerita asal usul Reog yang berkembang di masyarakat. Salah satu versi cerita yang terkenal adalah cerita tentang pemberontakan Ki Ageng Kutu, seorang abdi Kerajaan Majapahit, pada masa pemerintahan Raja Bhre Kertabhumi pada abad ke-15. Ia melihat Kerajaan Majapahit yang mulai runtuh oleh karena pengaruh kuat dari istri raja dan pemerintahan yang korup. Ki Ageng Kutu kemudian meninggalkan raja dan mendirikian perguruan yang mengajarkan anak- 
anak muda seni bela diri, ilmu kekebalan diri, dan ilmu kesempurnaan. Ia berharap bahwa anak-anak muda kelak akan memulihkan Kerajaan Majapahit. Ki Ageng Kutu sadar bahwa pasukannya terlalu kecil untuk melawan pasukan kerajaan, sehingga ia menyampaikan pesan sindirannya kepada Raja Kerthabumi dan kerajaannya melalui pertunjukan Reog. (Nugroho, 2018, pp. 3-4) Versi lain yang umum menceritakan tentang Raja Ponorogo yang ingin melamar Dewi Ragil Kuning, putri Kerajaan Kediri, tetapi ia dicegat oleh Raja Singabarong di tengah perjalanan. Pasukan Raja Singabarong terdiri dari merak dan singa, sedangkan pasukan raja Kelono dan wakilnya Bujang Anom, dikawal oleh warok yang memiliki ilmu hitam mematikan. Warok melakukan tarian-tarian perang antara Kerajaan Kediri dan Kerajaan Ponorogo, mengadu ilmu hitam antara keduanya sehingga para penari dalam keadaan "kerasukan" saat mementaskan tariannya (Nugroho, 2018, p.4).

2. Observasi

Observasi dilakukan pada 1 siswa laki-laki sekolah dasar Kalam Kudus Malang dalam rentang waktu 1 hari dengan beberapa variabel, yaitu kegiatan anak pada waktu luang, intensitas anak melihat film atau video, platform atau media yang sering anak gunakan untuk melihat film atau video, konten dan gaya film atau video yang sering dilihat anak, dan durasi film atau video yang dilihat anak.

Hasil yang diperoleh dari observasi yang telah dilaksanakan adalah:

a. Anak suka menonton video dan bermain game pada waktu luang.

b. Anak menonton film atau video selama 3-4 jam dalam 1 hari.

c. Platform yang digunakan anak untuk menonton video adalah Youtube.

d. Konten yang paling sering ditonton anak adalah konten menghibur dan atau edukatif seperti video komedi, pemain video game, dan penjelasan sejarah. Gaya video yang cenderung ditonton adalah live action dan footage rekaman, tetapi anak juga terkadang menonton film atau video bergaya kartun.

e. Durasi film atau video yang ditonton anak berdurasi 1 menit hingga 30 menit.

3. Wawancara

Wawancara dilakukan terhadap 27 siswa laki-laki dan perempuan sekolah dasar Kalam Kudus Malang dan Indriyasana Malang secara tatap muka dan daring. Pada wawancara tatap muka jawaban disimpan dengan rekaman suara, sedangkan pada wawancara daring jawaban disimpan dengan google form. Berikut pertanyaan-pertanyaan serta presentase terbesar jawaban dari setiap pertanyaan:

a. . 'Apa yang kamu suka lakukan ketika ada waktu luang?"

$62,9 \%$ anak menjawab bahwa mereka suka bermain atau menonton gadget pada waktu luang.

b. "Apakah kamu suka menonton film atau video?" $88,9 \%$ anak menjawab bahwa mereka suka menonton film atau video.

c. "Di mana kamu suka menonton film atau video?" 59,3\% anak menjawab bahwa mereka suka menonton film atau video di Youtube.

d. “Apa tontonan yang kamu suka?" 51,8\% anak menjawab bahwa mereka suka menonton kartun (2D \& 3D).

e. “Apakah kamu suka menonton kartun?" 55,6\% anak menjawab bahwa mereka suka menonton kartun.

f. "Jika iya, kartun apa yang kamu sukai?" $20 \%$ anak menjawab bahwa mereka menyukai kartun Upin $\&$ Ipin.

g. “Apakah kamu suka cerita rakyat?" 55,6\% anak menjawab bahwa mereka menyukai cerita rakyat.

h. "Jika iya, cerita rakyat apa yang kamu sukai?" 43,7\% anak menjawab bahwa mereka menyukai cerita rakyat Malin Kundang.

i. "Apakah kamu tahu cerita Asal Usul Reog Ponorogo?"

$70,4 \%$ anak menjawab bahwa mereka tidak mengetahui cerita Asal Usul Reog Ponorogo.

j. "Dari tiga gambar ini, manakah yang paling kamu sukai?"

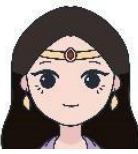

1

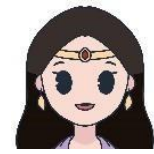

2

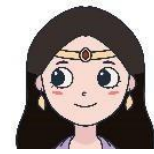

3
$63 \%$ anak menjawab bahwa mereka menyukai gambar 1

k. "Apakah kamu tertarik untuk menonton film kartun tentang cerita rakyat?" 70,4\% anak menjawab bahwa mereka tertarik untuk menonton film kartun tentang cerita rakyat.

Metode analisis data yang digunakan pada perancangan ini adalah $5 \mathrm{~W}+1 \mathrm{H}$. Pengumpulan data observasi, wawancara, dan studi pustaka dilakukan untuk memperoleh data-data yang kemudian di analisis dengan metode $5 \mathrm{~W}+1 \mathrm{H}$. Hasil analisis dari 6 pertanyaan tersebut akan membentuk suatu sintesis yang mendasari konsep perancangan. Hasil analisis pertanyaan what (apa) menyatakan bahwa anak-anak Sekolah Dasar memiliki pengetahuan dasar mengenai cerita rakyat, sebagian besar hanya mengetahui cerita rakyat yang umum diceritakan di sekolah. Cerita rakyat Indonesia bukan merupakan pilihan utama mereka dalam menonton atau membaca. Hasil analisis pertanyaan who (siapa) menyatakan 
bahwa demografis yang efektif dalam perancangan ini adalah anak-anak Sekolah Dasar yang memiliki ketertarikan terhadap kartun dan atau cerita rakyat. Hasil analisis pertanyaan why (mengapa) menyatakan bahwa cerita rakyat merupakan budaya literatur yang perlu dilestarikan karena merupakan literatur asli Indonesia yang banyak mengandung nilai moral dan nilai sejarah yang penting dipelajari oleh anak-anak. Hasil wawancara juga menyatakan bahwa sebagian besar anakanak masih tertarik dengan cerita rakyat dan lebih tertarik jika cerita rakyat disampaikan dengan media film kartun. Hal ini merupakan kesempatan yang baik untuk terus memperkenalkan cerita rakyat kepada anak-anak. Hasil analisis pertanyaan when (di mana) menyatakan bahwa waktu yang efektif dalam memberikan pembelajaran mengenai cerita rakyat kepada anak-anak adalah saat pelajaran sekolah dan pada waktu luang di rumah. Analisis ini didapatkan dari hasil observasi dan wawancara yang menunjukkan bahwa sebagian besar anak-anak suka menonton kartun pada waktu luang dan tertarik terhadap cerita rakyat. Jika pembelajaran cerita rakyat di sekolah dikemas dalam bentuk kartun, maka anak-anak akan lebih antusias untuk menonton karena pembelajaran dilakukan seperti kegiatan refreshing yang mereka gemari. Hasil analisis pertanyaan where (di mana) menyatakan bahwa peletakan video animasi yang tepat adalah platform yang paling sering diakses oleh anak-anak untuk menonton film atau video, yaitu Youtube. Hasil analisis pertanyaan how (bagaimana) menyatakan bahwa perancangan video animasi 2D Asal Usul Reog Ponorogo akan dengan beberapa tahap, yaitu alur, naskah, desain karakter dan background, storyboard, animatic, animate, dan post-production. Kesimpulan yang diperoleh berdasarkan analisis-analisis data tersebut adalah bahwa anak-anak Sekolah Dasar tertarik dengan cerita rakyat yang disampaikan dalam bentuk kartun yang menghibur. Selain itu, video animasi akan lebih efektif jika diunggah di internet karena mudah diakses dan bisa menjangkau banyak anak.

Alur cerita Asal Usul Reog Ponorogo pada perancangan ini memiliki beberapa adegan yang dimodifikasi dan berbeda dengan cerita Asal Usul Reog Ponorogo pada umumnya. Hal ini dilakukan dengan pertimbangan bahwa target audiens perancangan animasi ini adalah anak-anak sehingga perlu ditambahkan unsur yang menghibur tetapi tetap edukatif, sehingga inti cerita tidak diubah. Berikut merupakan alur cerita perancangan animasi Asal Usul Reog Ponorogo.

Dewi Sanggalangit menolak semua lamaran raja dan pangeran.
Dewi Sanggalangit mengatakan kepada orangtuanya bahwa ia
ingin calonnya menghadirkan pertunjukan tarian dan musik,
140 ekor kuda kembar, dan hewan berkepala dua.
Raja Kediri mengadakan sayembara.
Raja Kelana Swandana dan Raja Singabarong bersedia
memenuhi persyaratannya.
Raja Kelana Swandana bersama rakyatnya bersama bekerja
keras mengumpulkan hal-hal yang diperlukan. Raja

Singabarong melihat persiapan Raja Kelana Swandana dan berencana untuk merampasnya.

Raja Kelana Swandana mengetahui rencana tersebut dan menjadi marah, ia kemudian melakukan penyerangan terhadap Kerajaan Lodaya (Raja Singabarong).

Raja Singabarong sedang bersantai di istannya dengan burung meraknya yang mematuki kutu-kutu di rambutnya. Ia tidak mengetahui peperangan yang terjadi di luar.

Raja Kelana Swandana memasuki istana dan bertarung

Raja Kelana Swandana memasuki istana dan bertarung dengan Raja Singabarong.

Raja Singabarong kalah dan dengan kekuatan saktinya, Raja Kelana Swandana mengubah Raja Singabarong menjadi satu dengan burung merak yang berada di kepalanya. Pada hari pelamaran Raja Kelana Swandana membawa semua persyaratan termasuk hewan berkepala dua. Dewi Sanggalangit menerima lamaran

Raja Kelana Swandana.

Alur cerita ini masih berbentuk kalimat-kalimat inti cerita, sehingga perlu dikembangkan lagi menjadi suatu naskah dengan paragraph-paragraf yang menjelaskan cerita dengan lebih rinci. Berikut merupakan naskah hasil pengembangan alur cerita.

[Kerajaan Kediri]

Seorang raja dari suatu kerajaan mendatangi Kerajaan Kediri untuk melamar Dewi Sanggalangit. Dewi Sanggalangit langsung menolak lamaran tersebut dan Raja Kediri, ayah dari Dewi Sanggalangit, melihat kejadian itu.

Hari-hari berikutnya, raja-raja lain juga datang ke Kerajaan Kediri dan Dewi Sanggalangit menolak semuanya. Raja Kediri merasa khawatir dan bertanya kepada Dewi Sanggalangit mengapa ia menolak semua lamaran itu. Dewi Sanggalangit mengatakan bahwa ia ingin calon suaminya untuk menghadirkan pertunjukkan tarian dengan musik, 140 kuda kembar, dan hewan berkepala dua. Raja merasa keberatan tetapi tetap mengadakan sayembara bagi siapapun yang ingin melamar putrinya.

Raja Kediri mengumumkan sayembara tersebut di Kerajaan Kediri dan sekitarnya. Calon-calon yang awalnya ingin melamar Dewi Sanggalangit mengurungkan niatnya karena melihat persayaratannya. Akhirnya tersisalah dua orang yaitu Raja Kelana Swandana dari Kerajaan Bandarangin dan Raja Singabarong dari Kerajaan Lodaya yang bersedia mengikuti sayembara tersebut.

[Kerajaan Bandarangin]

Raja Singabarong tidak ingin mengumpulkan syarat-syarat itu sendiri, sehingga ia berencana untuk merampas kerja keras Raja Kelana Swandana. Raja Singabarong bersama patihnya mengintai ke Kerajaan Bandarangin dan mendapati bahwa Raja Kelana Swandana bersama rakyatnya bekerja sama untuk melakukan persiapan. Ketika Raja Singabarong hendak pergi, ia tidak sengaja menyenggol sebuah kendi kecil. Seorang 
penduduk yang mendengar suara itu kemudian melihat Raja Singabarong dan patihnya segera kabur. Penduduk yang menyadari bahwa itu adalah Raja Singabarong kemudian melaporkan hal tersebut kepada Raja Kelana Swandana.

[Istana Kerajaan Bandarangin]

Raja Kelana Swandana yang mengetahui sifat buruk Raja Singabarong kemudian menjadi geram dan langsung melaksanakan penyerangan terhadap Kerajaan Lodaya. [Kerajaan Lodaya]

Kerajaan Lodaya mendapat serangan tiba-tiba dan para prajurit dari dua kerajaan bertarung. Sementara itu, Raja Singabarong sedang berada di taman istana bersama burung merak miliknya yang mematuki kutu-kutu di kepalanya. Ia tidak mengetahui apa yang terjadi di luar karena ia tidak ingin diganggu ketika sedang dipatuki oleh meraknya.

[Taman Istana Kerajaan Lodaya]

Raja Singabarong terkejut ketika Raja Kelana Swandana tiba-tiba memasuki tamannya. Merekapun berkelahi dengan merak yang masih berada di atas kepala Raja Singabarong. Melihat itu, Raja Kelana Swandana mendapat suatu ide untuk memenuhi satu persyaratan Dewi Sanggalangit yang paling sulit. Raja Kelana Swandana kemudian menggunakan cambuk saktinya untuk mengalahkan Raja Singabarong dan mengubahnya menjadi binatang berkepala dua.

[Kerajaan Kediri]

Raja Kelana Swandana membawa semua persiapannya ke Kerajaan Kediri. Ia membawa 140 ekor kuda kembar dengan pertunjukan tarian yang diiringi dengan musik dan tetabuhan dan gamelan. Raja Kelana Swandana juga membawa hewan berkepala singa dan merak yang menari-nari. Putri Dewi Sanggalangit yang terpukau dengan pertunjukan tersebut akhirnya menerima lamaran dari Raja Kelana Swandana.

Desain karakter pada perancangan ini menggunakan style yang sederhana agar lebih mudah dianimasikan dan lebih mudah dikenali oleh anak-anak. Desain yang dipakai juga dibuat berdasarkan hasil wawancara yang telah dilakukan. Menurut Peaty dan Kirkpatrick (2002), desain karakter sebaiknya terlihat kompak secara visual, sesuai dengan cerita, dan menyatukan elemen-elemen visual yang ada. Tampilan karakter dan background pada perancangan ini secara general merujuk kepada penampilan orang-orang dan latar pada zaman kerajaan Indonesia, tetapi disesuaikan untuk terlihat lebih sederhana.

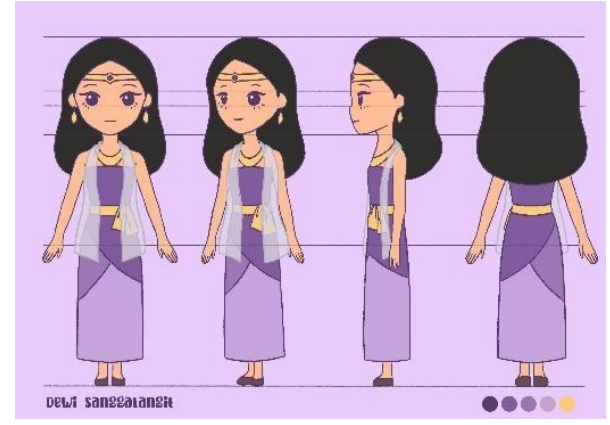

Gambar 2. Character Sheet Dewi Sanggalangit 1

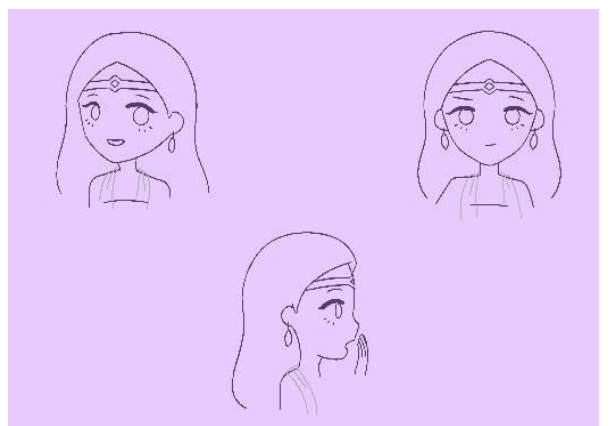

Gambar 3. Character Sheet Dewi Sanggalangit 2

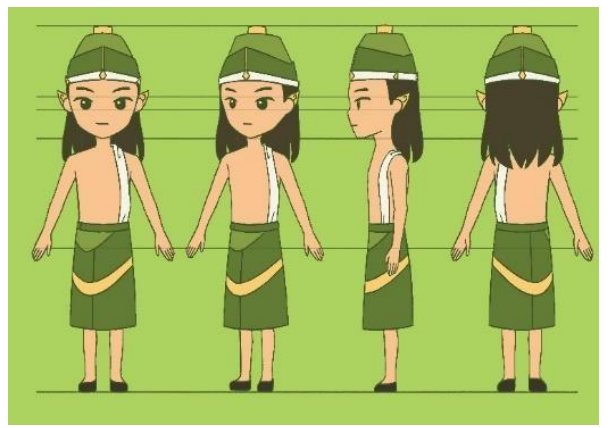

Gambar 4. Character Sheet Kelana Swandana 1

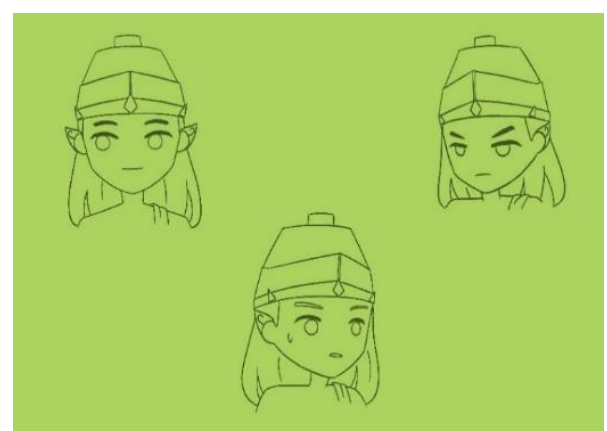


Gambar 5. Character Sheet Kelana Swandana 2

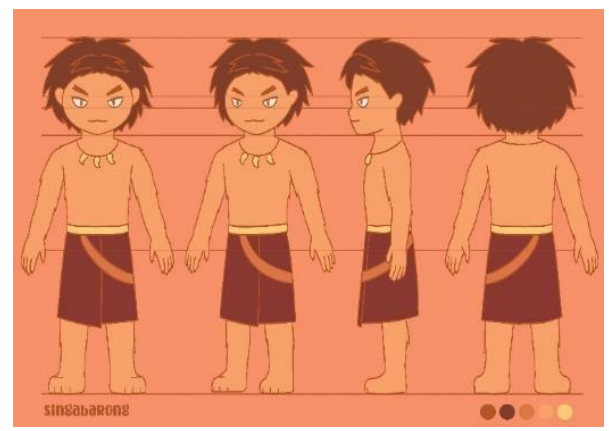

Gambar 6. Character Sheet Singabarong

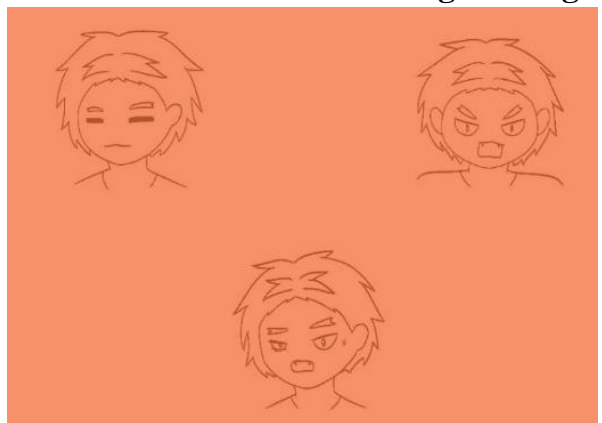

Gambar 7. Character Sheet Singabarong 2

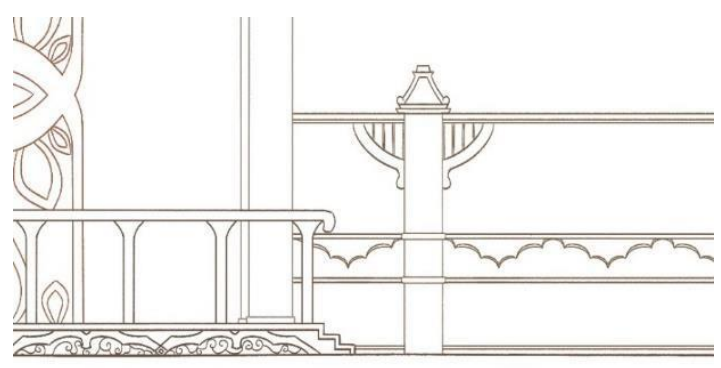

Gambar 8. Background Istana Kerajaan Kediri

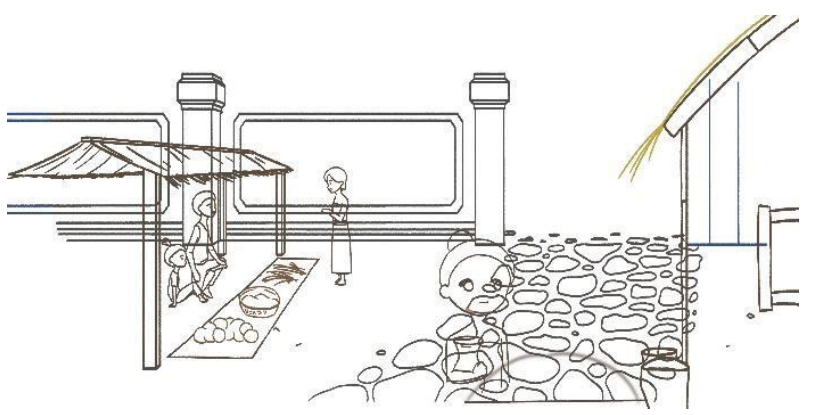

Gambar 9. Background Kerajaan Bandarangin

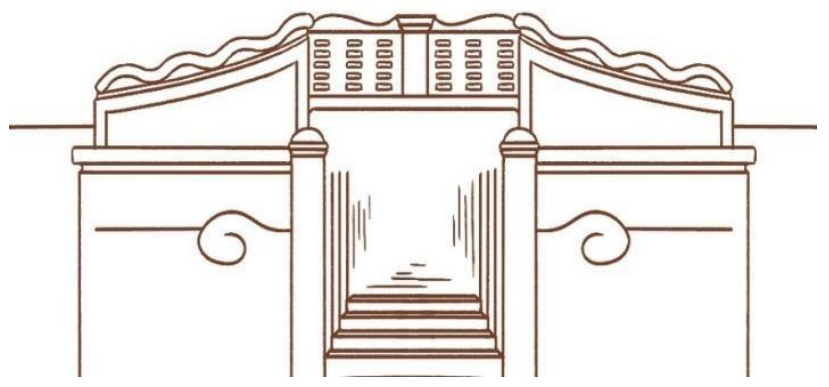

Gambar 10. Background Istana Kerajaan Lodaya

\section{Tata Visual Desain}

1. Media Utama

a. Storyboard

Storyboard adalah bentuk visualisasi kasaran dan pokok dari setiap adegan dalam animasi yang menunjukkan layout, angle, suasana, sequence, cut, dan dialog (Soenyoto, 2017). Pada perancangan ini, storyboard dikerjakan dengan perangkat lunak Paint Tool SAI dan 9B Pencil tool. Terdapat 75 panel yang dihasilkan berdasarkan naskah, desain karakter, serta background yang telah dikembangkan.
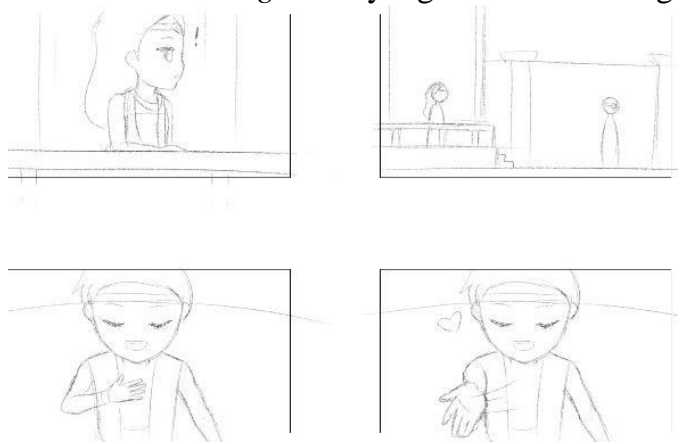

Gambar 11. Storyboard 1-4
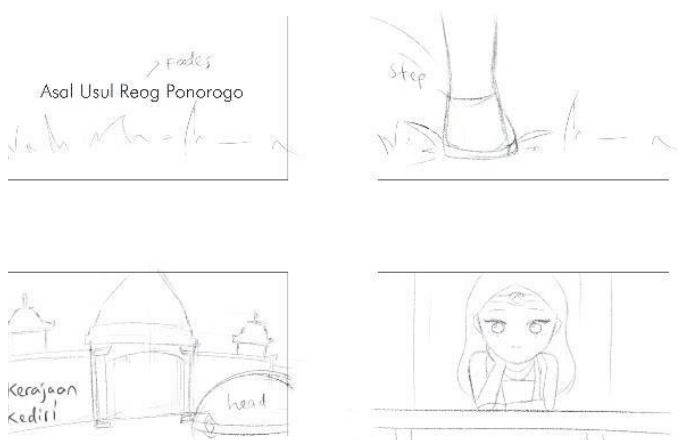


\section{Gambar 12. Storyboard 5-8}
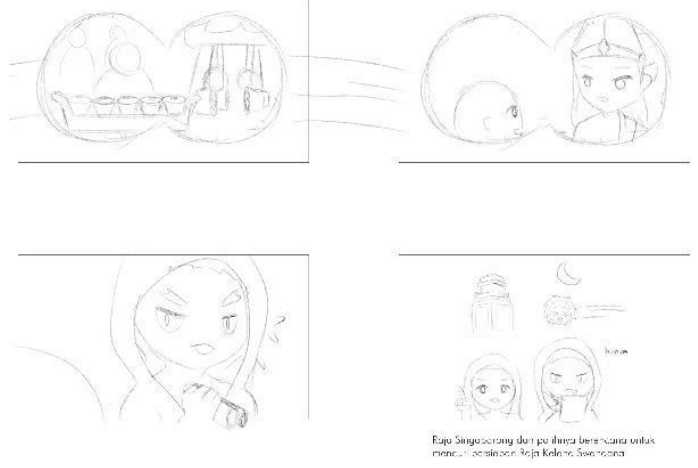

\section{Gambar 13. Storyboard 33-36}
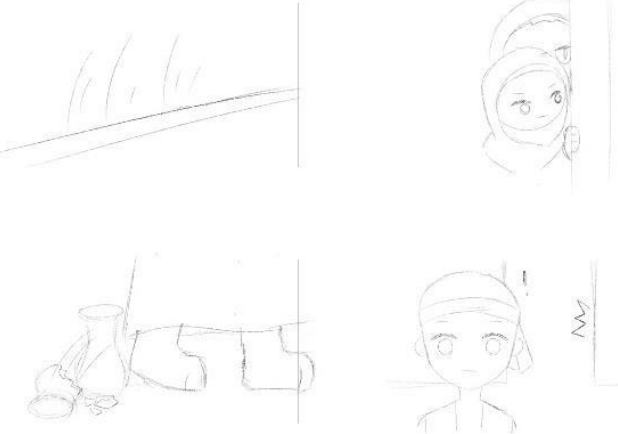

Gambar 14. Storyboard 37-40
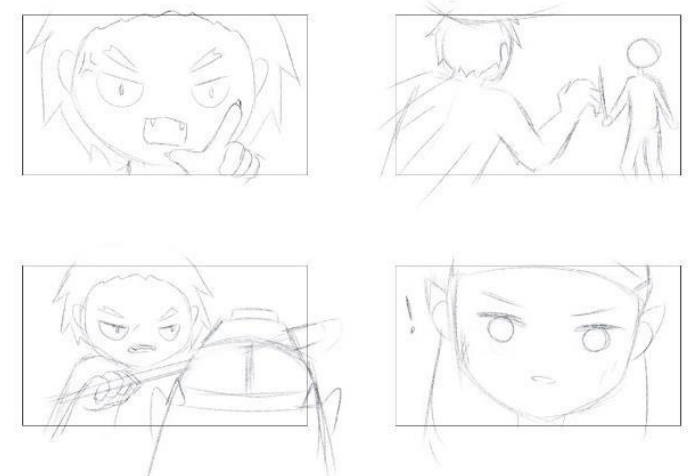

Gambar 15. Storyboard 57-60

\section{b. Animatic}

Animatic adalah visualisasi konsep dalam bentuk video berdasarkan storyboard yang telah dibuat. Timing, layout, camera movement, dan pose gerakan karakter diperjelas pada tahap ini. Animatic juga merupakan proses pengkajian konsep adegan dari storyboard sehingga bisa diperbaiki atau dirubah (Soenyoto, 2017). Tidak banyak perubahan yang dilakukan pada tahap ini, hanya terdapat perubahan-perubahan minor seperti ekspresi karakter atau angle shot. Animatic dibuat dengan menggunakan perangkat lunak Clip Studio Paint dan design pencil tool. Warna outline masih bersifat sementara dan akan diubah pada tahap selanjutnya. Berikut merupakan beberapa adegan dari animatic yang telah dibuat.
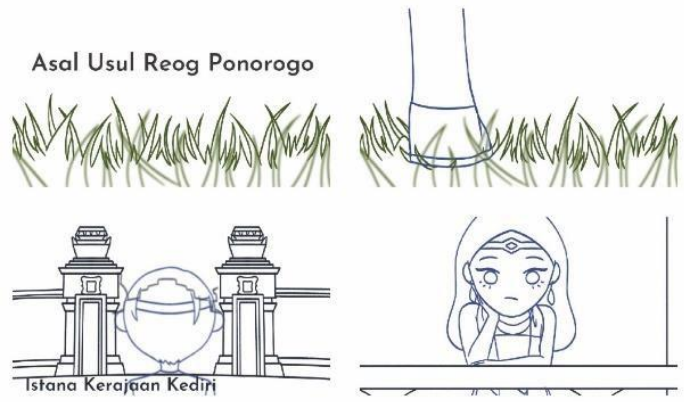

Gambar 16. Animatic 1-4
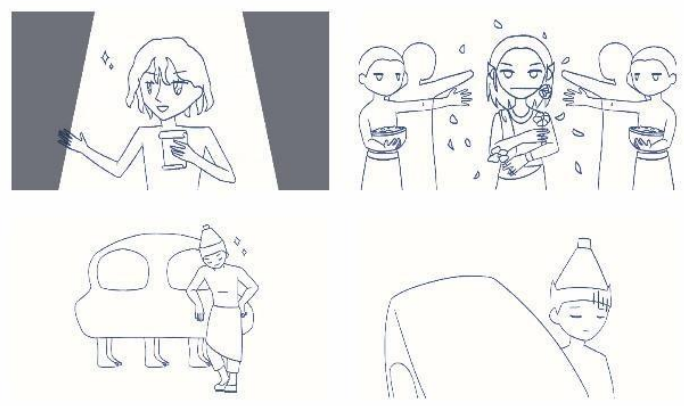

Gambar 17. Animatic 13-16

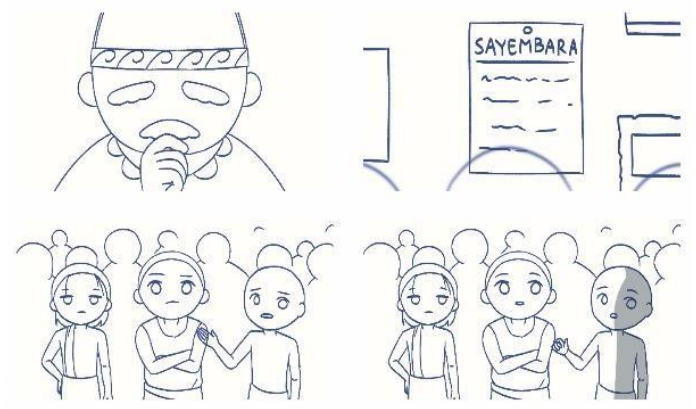

Gambar 18. Animatic 21-24
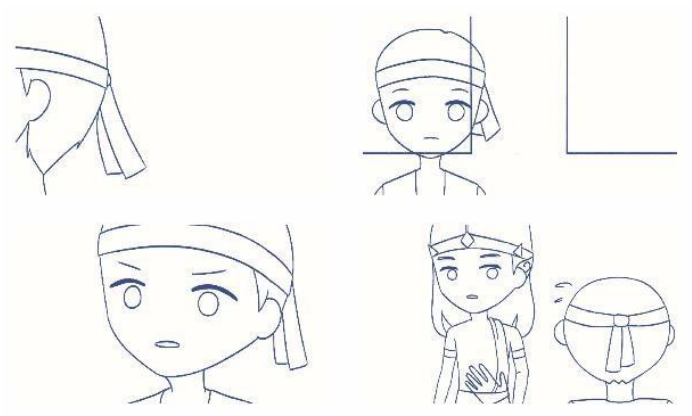

Gambar 19. Animatic 45-48 

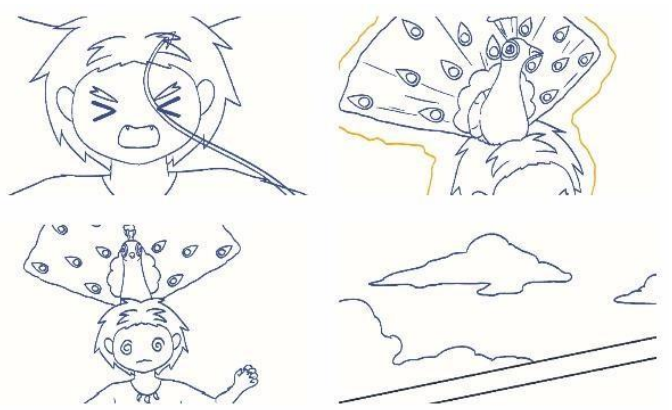

Gambar 20. Animatic 65-68

\section{c. Animation}

Pada tahap animating, adegan-adegan mulai dianimasikan atau digerakkan. Proses ini dimulai dengan menggambar key poses, yaitu gerakan-gerakan inti yang dilakukan oleh karakter dari awal hingga akhir. Setelah key pose, proses dilanjutkan dengan menggambar inbetween, yaitu gambar-gambar sekuens yang berfungsi sebagai perantara pose satu dengan pose selanjutnya (Soenyoto, 2017). Animasi pada tahap ini berdurasi 2 menit dan 31 detik dengan frame rate (kecepatan gambar atau frame) 12fps. Perangkat lunak yang digunakan untuk proses ini adalah Clip Studio Paint dengan design pencil tool Berikut merupakan beberapa gambar inbetween yang telah dibuat.

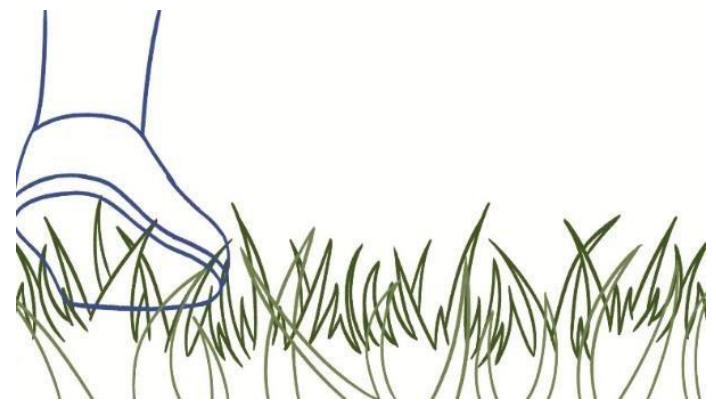

Gambar 21. Inbetween pada Scene 1

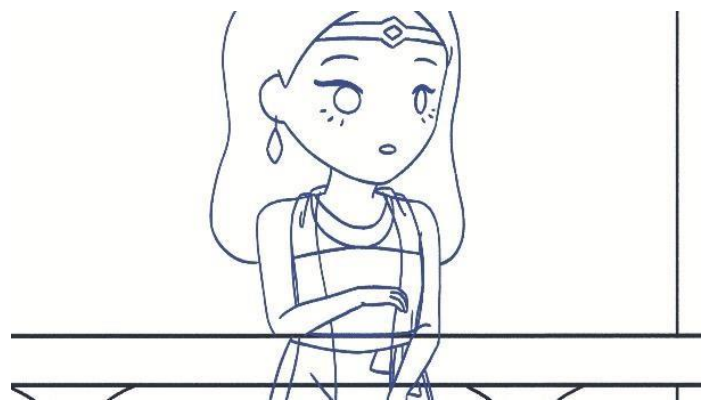

Gambar 22. Inbetween pada Scene 4

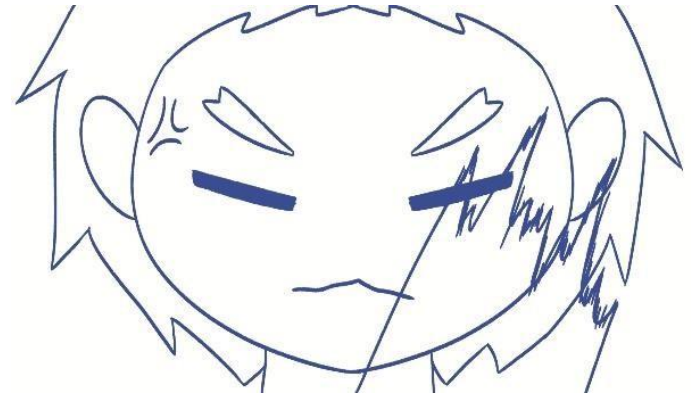

Gambar 23. Inbetween pada Scene 57

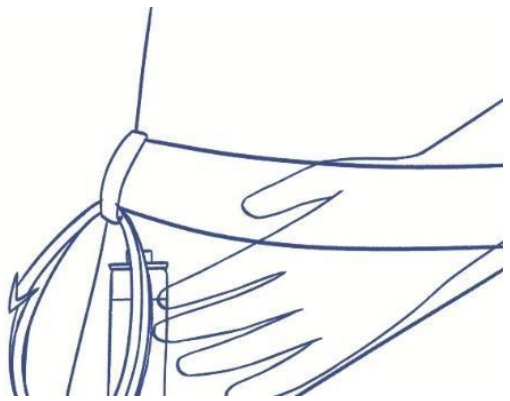

Gambar 24. Inbetween pada Scene 63

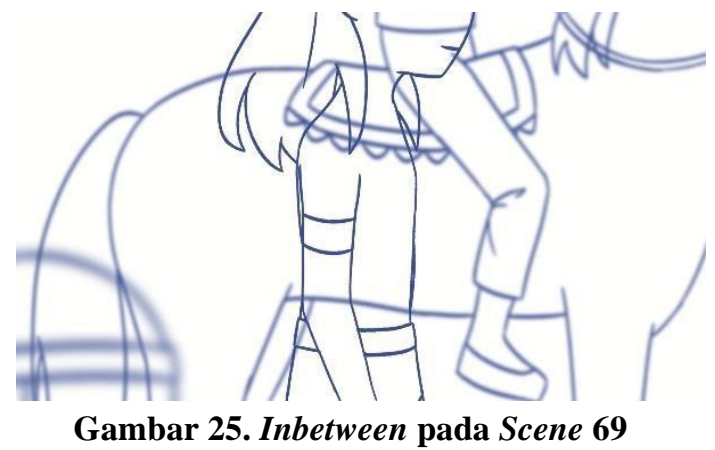

d. Coloring

Pewarnaan karakter pada animasi ini dilakukan dengan sederhana, yaitu flat coloring. Pewarnaan background dilakukan menggunakan beberapa gouache brush tool dengan teknik rendering yang simpel. Semua proses pewarnaan dilakukan menggunakan perangkat lunak Clip Studio Paint dengan bucket tool, gouache brush, dry gouache brush, thin gouache brush, dan gouache blender. Tiga karakter utama dengan karakter-karakter pendukung dapat dibedakan melalui warnanya, begitu juga dengan masingmasing latar kerajaan. Karakter Dewi Sanggalangit berwarna dominan ungu, Kelana Swandana berwarna dominan hijau, Singabarong berwarna dominan jingga, sedangkan karakter pendukung dominan berwarna coklat. Warna background pada Kerajaan Kediri berwarna dominan hijau dan putih, Kerajaan Bandarangin berwarna dominan kuning dan coklat, dan Kerajaan Lodaya berwarna dominan jingga dan merah. Kesan warna yang ditampilkan adalah hangat dan cerah. Secara keseluruhan, warna yang banyak digunakan adalah 
warna-warna hangat dengan saturasi menegah hingga tinggi. Warna dingin yang dipakai juga memiliki warm undertone sehingga dapat terlihat menyatu dengan warna lainnya. Berikut merupakan beberapa gambar coloring animasi yang telah dibuat.
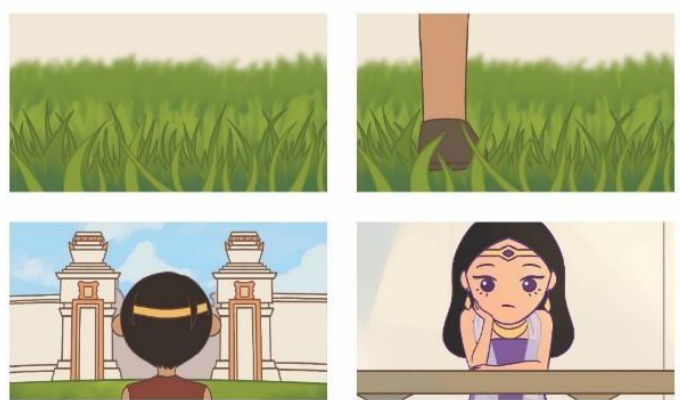

Gambar 26. Coloring 1-4
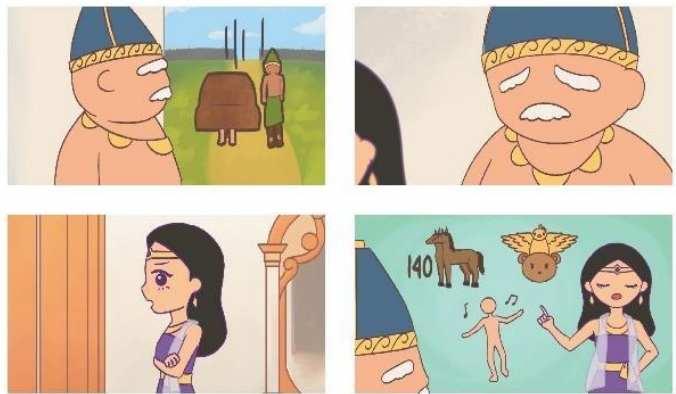

Gambar 27. Coloring 17-20
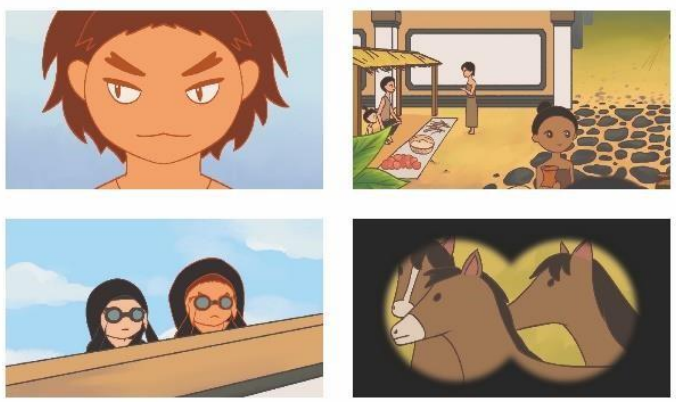

Gambar 28. Coloring 29-32
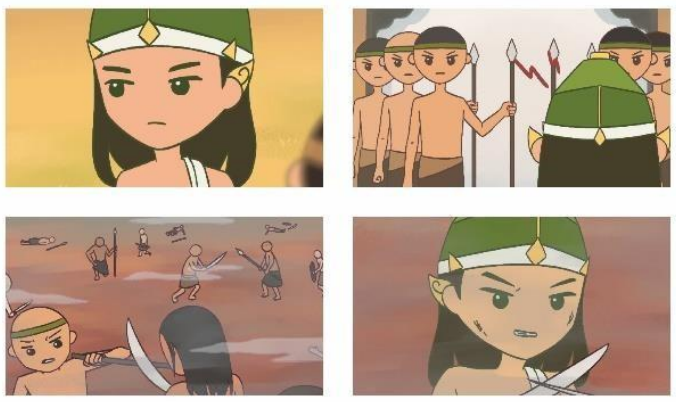

Gambar 29. Coloring 49-52
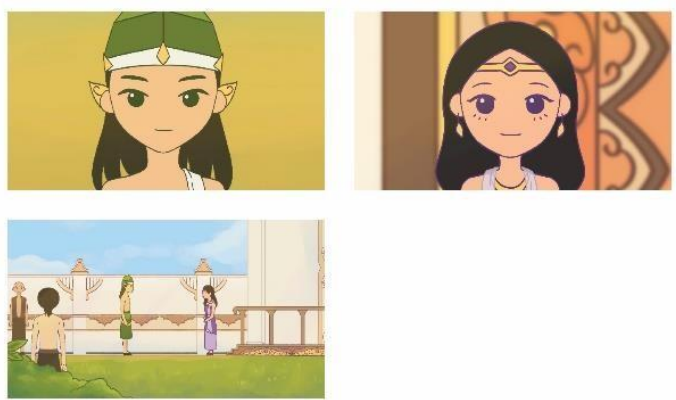

Gambar 30. Coloring 73-75

e. Post-production

Proses post-production animasi ini dilakukan dengan menggunakan menggunakan perangkat lunak Adobe After Effects. Elemenelemen yang ditambahkan pada post-production adalah logo judul, voice over, musik, sound effects, transisi, teks, dan credit title. Berikut merupakan penjabaran dari beberapa elemen.

1) Typeface

abCdefghijkLmnOPqRStUUWXYZ ABCOEFGHIJKLMNOPORSTUUWXYZ 1234567890.:.: " (!?) +- ${ }^{*} /=$

Gambar 31. Caramel Sweets Typeface

abcdefghijklmnopqrstuvwxyz ABCDEFGHIJKLMNOPORSTUVWXYZ

1234567890.:, ' " (!?) +-*/=

Gambar 32. Josefin Sans Typeface

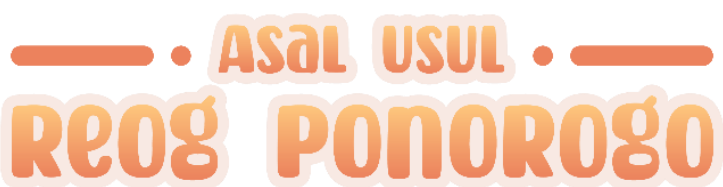

Gambar 33. Logo Asal Usul Reog Ponorogo

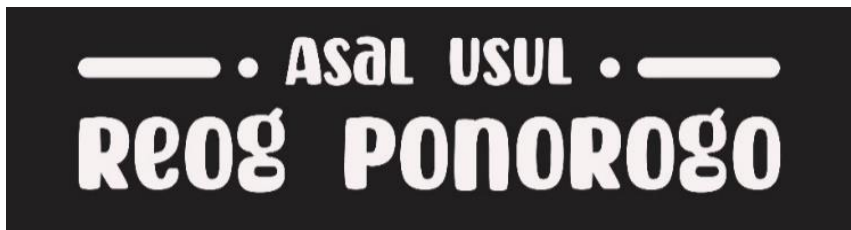

Gambar 34. Logo Asal Usul Reog Ponorogo

Typeface yang digunakan pada pada animasi adalah Caramel Sweets dan Josefin Sans. Caramel Sweets regular font digunakan pada logo dan media pendukung, sedangkan Josefin Sans medium bold dan Josefin Sans regular digunakan pada teks ending dan credit title. 
2) Audio

Audio voice over yang digunakan pada animasi dibuat oleh "y_maharani" dari situs jasa online yaitu, Fiverr. Audio tersebut berdurasi 4 menit dan 3 detik sehingga pada proses postproduction, timing video animasi disunting untuk menyesuaikan. Berikut merupakan voice over script yang digunakan.

Asal Usul Reog Ponorogo

Alkisah di Kerajaan Kediri, hiduplah seorang putri yang terkenal akan kecantikan dan kebaikannya, Putri tersebut bernama Dewi Sanggalangit.

Banyak raja dan pangeran dari berbagai tempat yang datang untuk melamarnya.

Tetapi

Putri Dewi Sanggalangit selalu menolak.

Ayahnya, Raja Kediri mulai khawatir.

Setelah melihat sekian banyaknya raja dan pangeran yang ditolak,

Akhirnya Raja menanyakan hal tersebut kepada putrinya

Dewi Sanggalangit berkata bahwa ia akan menerima

seseorang yang menghadirkan pertunjukan tari dan musik, 140

ekor kuda kembar, dan hewan berkepala dua.

Raja merasa keberatan, tetapi akhirnya memutuskan untuk mengadakan sayembara.

Semua calon menyerah setelah melihat persyaratannya,

Kecuali

Raja Singabarong dari Kerajaan Lodaya.

dan Raja Kelana Swandana dari Kerajaan Bandarangin.

Raja Singabarong yang dikenal jahat dan kejam memiliki

suatu rencana licik.

Raja Singabarong dan patihnya pergi mengintai ke Kerajaan

Bandarangin.

Mereka melihat bahwa Raja Kelana Swandana bersama rakyatnya bekerja sama untuk melakukan persiapan.

Raja Singabarong dan patihnya berencana untuk menyelinap pada malam hari untuk mencuri semua persiapan Raja Kelana Swandana dan kemudian melamar Dewi Sanggalangit.

Setelah selesai mengintai mereka mengendap-endap untuk
Setelah selesai mengintai mereka mengendap-endap untuk kembali ke Kerajaan Lodaya.

Tetapi Raja Singabarong tidak sengaja menyenggol sebuah kendi kecil.

Seorang penduduk yang mendengar suara itu

kemudian mendekat untuk melihat apa yang terjadi.

Raja Singabarong dan patihnya segera kabur.

Penduduk tersebut akhirnya menyadari bahwa itu adalah

Raja Singabarong dan melaporkannya kepada Raja Kelana

Swandana.

Raja Kelana Swandana yang mengetahui sifat buruk Raja Singabarong menjadi geram dan langsung melaksanakan penyerangan terhadap Kerajaan Lodaya.

Raja Kelana Swandanapun ikut berperang dan mencari Raja Singabarong

Raja Singabarong ternyata sedang berada di taman istana bersama burung meraknya yang mematuki kutu-kutu di kepalanya.

Raja Kelana Swandana akhirnya menemukan taman istananya. Raja Singabarong menjadi marah karena telah diganggu dan menyerang Raja Kelana Swandana.

Raja Kelana Swandana melihat merak yang masih ada diatas kepalanya dan mendapat ide untuk memenuhi persyaratan putri yang paling sulit

Raja Kelana Swandana kemudian menggunakan cambuk saktinya untuk mengalahkan Raja Singabarong dan mengubahnya menjadi binatang berkepala dua.

Raja Kelana Swandana membawa seluruh persiapannya ke Kerajaan Kediri.

140 ekor kuda kembar, tarian dan musik, serta hewan berkepala dua

Putri Dewi Sanggalangit yang terpukau dengan pertunjukan tersebut akhirnya menerima lamaran dari Raja Kelana

Swandana.

Moral dari cerita rakyat ini adalah bekerjalah dengan dengan jujur maka usahamu akan membuahkan hasil.

Selain itu, audio musik yang digunakan adalah "Enem" dan "Songo" yang diproduksi oleh Donkgedang. Sound effects diperoleh dari berbagai sumber yaitu zapslat.com, Youtube Audio Library, n Beats Youtube channel, Everything.mp4 Youtube channel, Free Audio Zone Youtube Channel, Rak Rak Youtube Channel, Cartoon Sound Effects, dan All Sounds.

\section{3) Credit Title}

Credit title berada pada akhir video setelah ending dan pesan moral. Credit title berdurasi sekitar 20 detik dan diawali dengan logo kemudian dilanjutkan susunan pihak-pihak yang terlibat dalam pembuatan. 


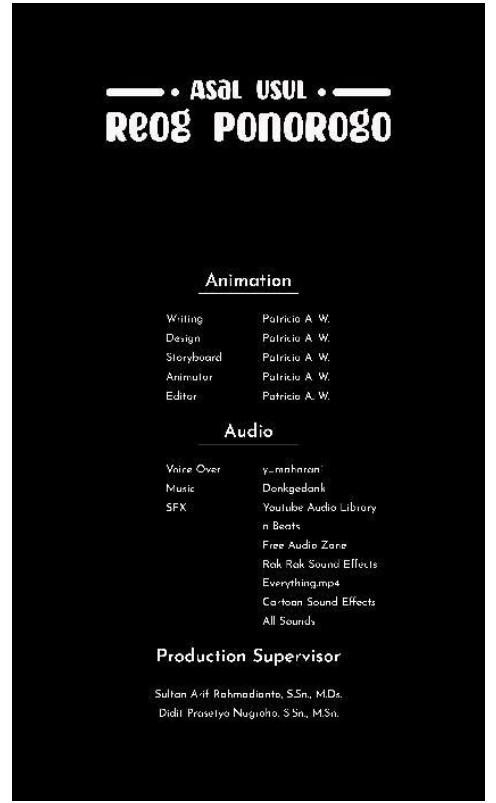

Gambar 35. Credit title

2. Media Pendukung

a. Video Teaser

Video teaser digunakan sebagai salah satu media promosi animasi. Video ini berdurasi 45 detik dan dibuat dengan perangkat lunak Adobe After Effects. Musik yang digunakan sama dengan musik pada video animasi, yaitu "Enem" oleh Donkgedang. Konten yang ditampilkan berupa cuplikan-cuplikan dari video animasi dengan teks dari voice over script diantaranya. Font yang digunakan adalah Josefin Sans medium. Pada bagian akhir teaser ditampilkan logo, Youtube channel dan akun Instagram yang akan menanyangkan animasi, serta waktu rilis.
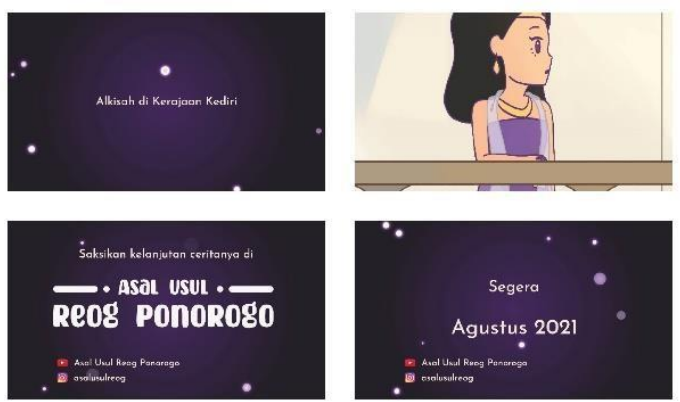

Gambar 36. Video Teaser Animasi Asal Usul Reog Ponorogo

b. Poster

Poster yang digunakan berukuran A4 potrait dan dibuat dengan perangkat lunak Clip Studio Paint. Poster berupa ilustrasi karakter-karakter pada animasi dan terdapat logo pada bagian bawah. Rendering warna dilakukan dengan menggunakan gouache brush, dry gouache brush, thin gouache brush, gouache blender, dan dense watercolor.

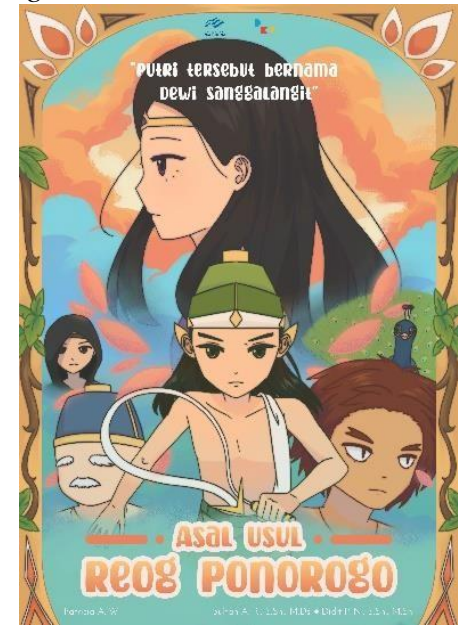

\section{Gambar 37. Poster Animasi Asal Usul Reog Ponorogo}

\section{c. Merchandise}

Media pendukung merchandise yang digunakan adalah gantungan kunci. Terdapat 3 desain gantungan kunci, yaitu ilustrasi Dewi

Sanggalangit, Kelana Swandana, dan Singabarong. Bahan gantungan kunci berupa akrilik dan ukuran gantungan kunci sedikit berbeda satu sama lain.

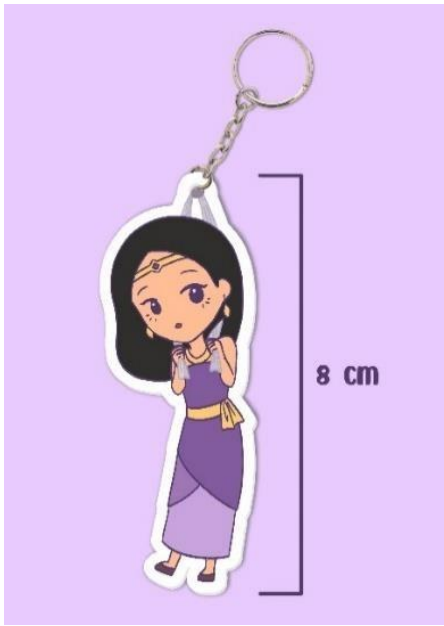

Gambar 38. Keychain Dewi Sanggalangit 


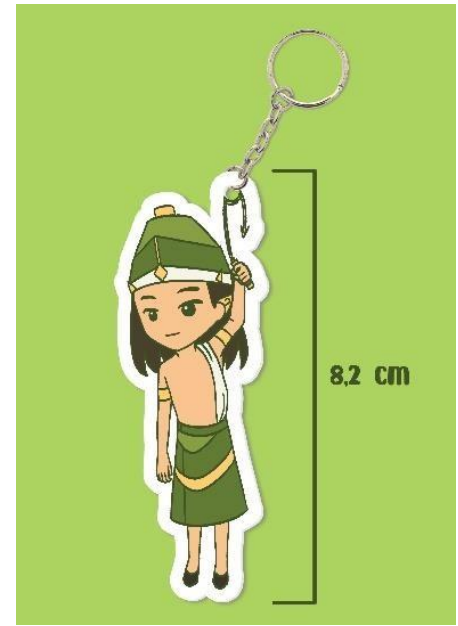

Gambar 39. Keychain Kelana Swandana

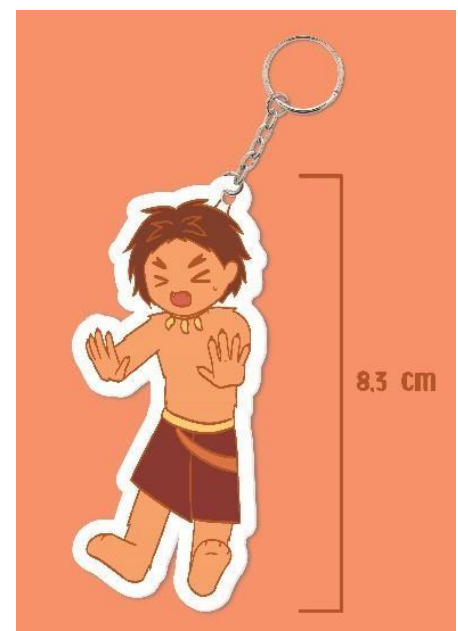

\section{Gambar 40. Keychain Singabarong}

3. Pameran Online

Pameran perancangan ini dilakukan secara online pada platform Instagram. Unggahan berupa 10 multiple feed post dan 1 IGTV post. Konten unggahan pada multiple feeds adalah video animasi berdurasi 1 menit, desaindesain karakter dan background, proses pembuatan, poster, dan merchandise. Konten unggahan pada IGTV adalah video animasi berdurasi penuh.
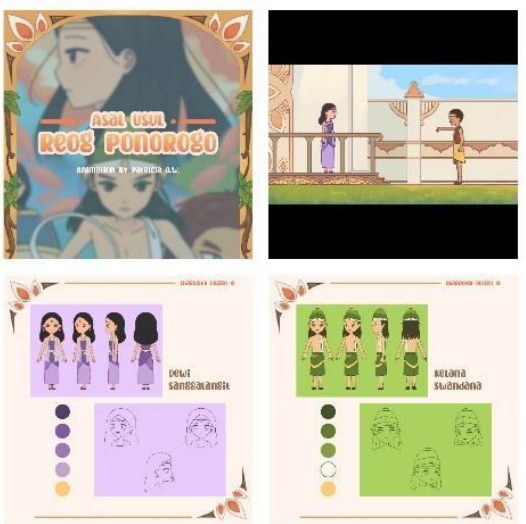

Gambar 41. Multiple Feed 1-4
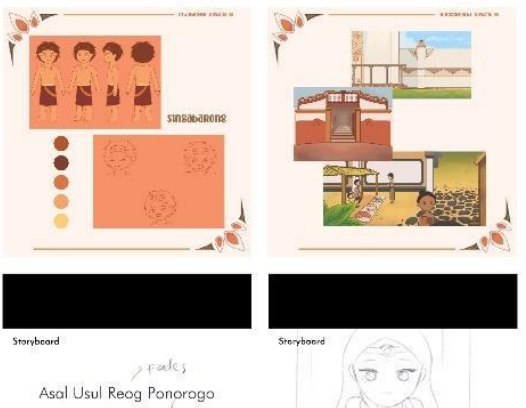

Asal Usul Reog Ponorogo

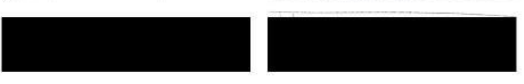

Gambar 42. Multiple Feed 5-8

patriciaa.w7

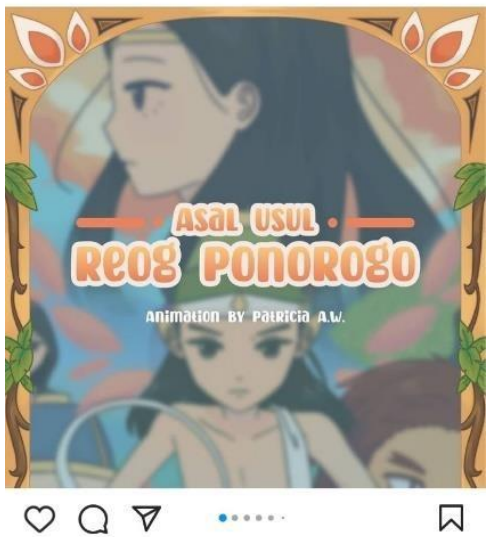

Gambar 43. Unggahan Multiple Feed pada Instagram 


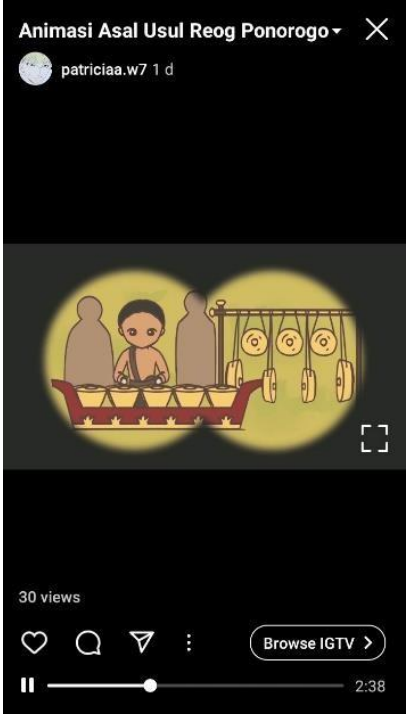

Gambar 44. Unggahan IGTV pada Instagram

\section{Kesimpulan}

Cerita rakyat adalah salah satu budaya literatur Indonesia yang perlu dilestarikan. Nilai luhur dan moral yang terdapat pada cerita-cerita rakyat penting untuk ditanamkan, khususnya pada anak-anak. Penyampaian cerita rakyat pada zaman dahulu dilakukan secara lisan dan kemudian secara tulisan, akan tetapi dengan berkembangnya zaman semakin dibutuhkan adanya media-media lain. Perancangan ini menggunakan media animasi sebagai media yang efektif dalam memberi pembelajaran kepada anak. Menurut pengumpulan dan analisis data yang telah dilakukan penulis, anak-anak masih memiliki ketertarikan terhadap cerita rakyat, tetapi kurang tahu tentang cerita-cerita itu sendiri. Cerita rakyat yang diadaptasi menjadi animasi 2D pada perancangan ini adalah Asal Usul Reog Ponorogo. Cerita ini baik untuk diketahui anak-anak karena mengandung nilai sejarah seni Reog Ponorog dan nilai moral tentang kejujuran. Pada perancangan ini penulis melakukan pengumpulan data dengan 3 metode, yaitu observasi, wawancara, dan studi pustaka. Observasi dilakukan terhadap 1 anak dengan variable-variabel pengamatan seputar behavior anak secara dalam mengkonsumsi konten general. Wawancara dilakukan dengan 27 anak secara tatap muka maupun melalui angket daring. Pertanyaan-pertanyaan wawancara berupa seputar preferensi tontonan anak. Studi pustaka dilakukan terhadap kesenian Reog Ponorogo. Setelah pengumpulan data, penulis melakukan analisis data yang menggunakan metode $5 \mathrm{~W}+1 \mathrm{H}$. Kesimpulan yang didapat adalah anak-anak secara general tertarik dengan kartun dan cerita rakyat, sehingga diharapkan bahwa adaptasi animasi mengenai cerita rakyat dapat diterima dengan baik. Proses pembuatan media utama dalam perancangan ini dimulai dari alur dan naskah cerita. Konsep secara tulisan kemudian divisualisasi secara kasaran pada tahap Storyboard. Setelah itu gambar-gambar dan arahan visual dari storyboard diperjelas dengan animatic yang berbentuk video. Animatic masih berupa kompilasi gambar dengan pergerakan kamera, dan pada tahap selanjutnya adeganadegan mulai digerakkan dengan proses menggambar key poses dan inbetween. Tahap produksi kemudian dilanjutkan dengan coloring. Post-production pada perancangan animasi ini adalah editing, penambahan teks, transisi, serta audio musik dan sfx. Selain media utama animasi $2 \mathrm{D}$, terdapat 3 media pendukung yang berupa video teaser, poster A4, dan juga merchandise gantungan kunci.

\section{Daftar Pustaka}

Awalia, I., Pamungkas, A.S. dan Alamsyah, T.P. (2019). Pengembangan Media Pembelajaran Animasi Powtoon pada Mata Pelajaran Matematika di Kelas IV SD, Jurnal KREANO, 10:49-56.

Budiman (1999). Folklore Betawi. Pustaka Jaya

Denzin, N.K. and Lincoln, Y.S. (2005). The Sage Handbook of Qualitative Research. $3^{\text {rd }}$ edition. Sage

Creswell, J.W. (2007) Qualitative Inquiry \& Research Design. Sage

Departemen Pendidikan dan Kebudayaan. (1978/1979). Reog di Jawa Timur. Proyek Sasana Budaya Direktorat Jenderal Kebudayaan Departemen Pendidikan dan Kebudayaan.

Gall, M. D., Gall, J.P. and Borg, W.R. (2003). Educational Research: An Introduction. $7^{\text {th }}$ edition. Pearson.

Handayani, H., Putra, F.G. dan Yetri, Y. (2018). Pengembangan Media Pembelajaran Berbasis Macromedia Flash, Tatsqif, 16:87-100.

Hernando, E. (2018). Bela Diri Tradisional Suku Dayak Kalimantan Tengah (Sebuah Kajian Sejarah, Filosofi, dan Teknik Seni Bela Diri Tradisional). Tesis MPd, Fakultas Ilmu Keolahragaan, Universitas Negri Yogyakarta.

Imamah, N. (2012). Peningkatan Hasil Belajar IPA Melalui Pembelajaran Kooperatif Berbasis Konstruktivisme Dipadukan Dengan Video Animasi Materi Sistem Kehidupan Tumbuhan, Pendidikan IPA Indonesia, 1:3236.

Kirkpatrick, G. and Peaty, K. (2002). Flash Cartoon Animation. Apress.

Kristanto, M. (2014) Pemanfaatan Cerita Rakyat Sebagai Penanaman Etika untuk Membentuk Pendidikan Karakter Bangsa. Mimbar Sekolah Dasar. 1:59-64.

Lestari, P. A. dan Setiawan (2019). Adaptasi Cerita Rakyat Jayaprana dan Layonsari dalam Bentuk Animasi 2D. NAWALA VISUAL. 1:88-94.

Maharsi, I. (2016). Ilustrasi. Badan Penerbit ISI. 
Mahendra, R., Trisnadoli, A. dan Nugroho, E.S. (2018). Implementasi Teknik Sinematografi dalam Pembuatan Film Animasi 3D Cerita Rakyat "Batu Belah Batu Betangkup". RESTI. 2:578-583.

Marx, C. (2012). Writing for Animation, Comic, and Game. Focal Press, Waltham. USA.

Panjaitan, N. Q., Yetti, E. dan Nurani, Y., 2020, Pengaruh Media Pembelajaran Digital Animasi dan Kepercayaan Diri terhadap Hasil Belajar Pendidikan Agama Islam Anak, OBSESI, 4:588-596.

Prasetyo, D. (2018). Citing Internet Sources URL http://www.magisterseniusu.com/uploads/1/8/0/0/180034 0/dwi-prasetyo.pdf

Putra, I. E. (2013). Teknologi Media Pembelajaran Sejarah Melalui Pemanfaatan Multimedia Animasi Interaktif. TEKNOIF. 1:20-25.

Santyasa, I.W. (2007). Landasan Konseptual Media Pembelajaran. Makalah disajikan dalam workshop media pembelajaran bagi guru-guru SMA Negeri Banjar Angkan.

Soenyoto, P. (2017). Animasi 2D. Elex Media Komputindo.

Sugiyono (2015). Metode Penelitian Pendidikan (Pendekatan Kuantitatif, Kualitatif, $R \& D)$. ALFABETA.

Sumayana, Y. (2017). Pembelajaran Sastra di Sekolah Dasar Berbasis Kearifan Lokal (Cerita Rakyat). Mimbar Sekolah Dasar. 4:21-28.

Syahfitri, Y. (2011). Teknik Film Animasi dalam Dunia Komputer. SAINTIKOM. 10:213-217.

Thomas, F. and Johnston O. Illusion of Life. 1981. Disney Editions.

Tripungkasingtyas, Y. S. (2016). Pembelajaran Sastra di Sekolah Dasar Melalui Karya Sastra Cerita Rakyat sebagai Salah Satu Bentuk Pengenalan Budaya Nusantara. Jurnal S3pbi UNS. 1:518-522

Wuryanti, U., dan Kartowagiran. (2016). Pengembangan Media Video Animasi Untuk Meningkatkan Motivasi Belajar dan Karakter Kerja Keras Siswa Sekolah Dasar. Pendidikan Karakter. 6:232-245. 